\title{
Galvanic Corrosion Behavior of Copper-Drawn Steel for Grounding Grids in the Acidic Red Soil Simulated Solution
}

\author{
Xiao-Lei Fan ${ }^{1} \cdot$ Yun-Xiang Chen ${ }^{2} \cdot$ Jun-Xi Zhang $^{1} \cdot$ De-Yuan Lin ${ }^{2} \cdot$ Xuan-Xuan Liu $^{1} \cdot$ Xiao-Jian Xia $^{2}$
}

Received: 16 February 2020 / Revised: 18 March 2020 / Published online: 3 June 2020

(c) The Chinese Society for Metals (CSM) and Springer-Verlag GmbH Germany, part of Springer Nature 2020

\begin{abstract}
The influence of $\mathrm{pH}$ and metallographic structure on the corrosion behavior of copper-drawn steel is studied with the simulated system. The effect of $\mathrm{pH}$ on the corrosion behavior of copper-drawn steel has been investigated using open-circuit potential, potentiodynamic polarization, galvanic current measurement, scanning electron microscopy and scanning vibrating electrode technique techniques. The steel is corroded as anode, while the corrosion of copper plate is protected as cathode. All the results revealed that $\mathrm{pH}$ and metallographic structure had a significant influence on the corrosion behavior of copper-drawn steel. With the decrease in $\mathrm{pH}$ value from 6 to 2.4, the corrosion rate of copper-drawn steel galvanic couple ( $\mathrm{Cu}-\mathrm{Fe} \mathrm{GC}$ ) obviously increased in the simulated solution of acidic red soil. The electric field formed by the $\mathrm{Cu}-\mathrm{Fe} \mathrm{GC}$ changes the direction of ion migration between the copper and drawn steel electrodes, which impacts the composition and microstructure of corrosion products formed on the electrode surface.
\end{abstract}

Keywords $\mathrm{Cu}-\mathrm{Fe}$ galvanic couple $\cdot$ Electrochemical test $\cdot$ Scanning vibrating electrode technique (SVET) measurement . Soil corrosion

\section{Introduction}

Substation equipment serves in the field environment for a long time, which brings the corrosion of metal parts in the substation equipment, in particular for those buried underground. Grounding network structure is complex range throughout the transformer substation, and overhaul is very inconvenient during the period of maintenance. In other words, the selection of substation equipment materials to protect from the corrosion is a key issue to maintain the safe operation of substation equipment. Currently, the materials used for grounding grid in substation equipment are mainly from galvanized steel, copper-drawn steel, steel, etc. It was found that the iron-aluminum oxides in red soil can promote the corrosion of

Available online at http://link.springer.com/journal/40195

Jun-Xi Zhang

zhangjunxi@ shiep.edu.cn

1 Shanghai Key Laboratory of Materials Protection and Advanced Materials in Electric Power, Shanghai University of Electric Power, Shanghai 200090, China

2 Electric Power Research Institute of State Grid Fujian Electric Power Company Limited, Fuzhou 350007, China copper-clad steel [1]. With regard to the effect of chloride ions on corrosion of the materials used for grounding grid, it was found that the corrosion rate of zinc-clad steel increased with increasing chloride ions up to critical chloride concentration. Above critical chloride concentration, corrosion rate starts decreasing [2]. Wei et al. [3] studied the corrosion behavior of a thermal-sprayed stainless steel-coated Q235, galvanized steel and as-received Q235 steel as grounding grids in the simulated soil solution. The main corrosion form of buried metal is electrochemical corrosion [4]. Srikanth et al. [5] classified the form of soil corrosion into the following: (1) local corrosion caused by uneven materials; (2) stress corrosion cracking caused by $\mathrm{Cl}^{-}$and $\mathrm{S}^{2-}$ ion in the soil; (3) oxygen concentration cell caused by different oxygen contents in the area near the surface of metal materials in the soil; and (4) material corrosion in the soil is affected by stray current. Ismail et al. [6] estimated the risk of corrosion for the underground pipelines and steel structures. They concluded that many problems related to soil corrosion are due to the unfavorable interaction between water and soil. Wei et al. [7] studied that the change of $\mathrm{pH}$ had a great impact on the corrosion of carbon steel in the soil. The presence and activity of microorganisms in soil have certain influence on the corrosion of buried metal. Sulfate-reducing bacteria (SRB) are anaerobic bacteria, which can be found in 
oxygen-deficient soils. SRB can increase the corrosion process by producing hydrogen sulfide and transform non-corrosive soil into highly corrosive soil [8]. Li et al. [9] found that Brevibacterium halotolerans promote the corrosion of X80 steel. There are many other factors on metallic corrosion in soils, such as soil resistivity [10], water content [11-13], size and grade of soil [14], soil type [15, 16], soluble salt ions content [17] and pH [18]. Stray currents can also affect soil corrosion. Wei et al. [19] researched that the alternating current influenced the corrosion behavior of X80 steel and the increase in alternating current density accelerated the corrosion rate of X80 steel.

However, there are few reports about the galvanic corrosion in the soil environment. Copper-drawn steel as a good electrical conductivity, suitable strength and excellent corrosion resistance grounding grid material has been widely used in the soil environment. Some copper-drawn steel was manufactured using a cold-drawn process, while cold-drawn process affects the corrosion resistance of cold-drawn materials. Recently, there have been many researches on the corrosion resistance of cold-drawn steel [20-23], but no more reports on the galvanic corrosion between the cold-drawn steel and copper are published. When the copper coating on the surface of copper-drawn steel is damaged or the unclad two-end faces of the copper-drawn steel are exposed to soil environment, galvanic corrosion occurs due to the difference of potential between copper and steel, and the corrosion rate of the metal with a low potential will be increased.

Studies in aqueous environment have shown that there are many factors that can influence galvanic corrosion, such as the properties of the metal itself (potential difference between metals, polarization resistance [24], the stability of the passive film, etc.), geometric properties (galvanic couple of area ratio between cathode and anode [25, 26], the distance between electric dipoles [27, 28]), and environmental factors (the flow velocity of the medium [25, 29, 30], dissolved oxygen [31, 32], $\mathrm{pH}$ [33] and temperature [34-36]). In addition, organisms and some organic substances in the environmental medium will also affect the galvanic corrosion [37, 38].

On the surface of corroded metal, cathode process and anode process often occur in different areas. In these regions, the different reaction properties, reaction rates, ion formation and distribution in the solution will result in ion concentration gradient. The ion mobilization and distribution in the local area of the metal can be detected by scanning vibrating electrode technique (SVET) measurement. SVET may be used to study pitting corrosion, micro-galvanic corrosion and the electrochemical properties of the passive film in the micro-zone so as to better understand the mechanism of its occurrence [38-43]. Ni et al. [44] studied the typical polarity reversal of Cu-304SS galvanic couple (GC) in solution containing $\mathrm{Cl}^{-}$with different $\mathrm{pH}$ values by electrochemical test and SVET test. Manhabosco et al. [45] employed the microcapillary cell (MEC) and SVET and low-angle cross sections to elucidate the role of each coating region on the protection of the cut-edge corrosion of galvanized steels.

In this study, a simulated soil solution was employed for the corrosive environment of the red clay soil. The influence of $\mathrm{pH}$ and metallographic structure on the corrosion behavior of $\mathrm{Cu}-\mathrm{Fe}$ steel GC was studied by using the opencircuit potential (OCP), potentiodynamic polarization, galvanic current measurement, SVET and immersion tests. The corrosion mechanism of $\mathrm{Cu}-\mathrm{Fe}$ steel $\mathrm{GC}$ was discussed in this paper.

\section{Experimental}

\subsection{Materials and Simulated Solution Preparation}

The drawn steel 20 and copper (99.99 wt\%) were used as electrodes materials. The composition of the drawn steel 20 is listed in Table 1. The specification of the sample is a cylinder rod with a diameter of $10 \mathrm{~mm}$, surrounded by epoxy resin. The exposure area of the single electrode is $0.785 \mathrm{~cm}^{2}$. The galvanic couple electrode was made by separating copper and drawn steel with a PVC membrane and packed by epoxy resin (as shown in Fig. 1a). The samples for SVET were copper and drawn steel 20 wires with a diameter of $2 \mathrm{~mm}$ (as exhibited in Fig. 1b). The two electrodes were encapsulated in epoxy resin and separated by $1 \mathrm{~mm}$. The samples for weight loss experiment were drawn steel 20 and copper with a diameter of $10 \mathrm{~mm}$ and surrounded by epoxy resin. The distance between the two electrodes was $5 \mathrm{~mm}$. Each electrode was welded with copper wire to ensure the electric connection in the tests.
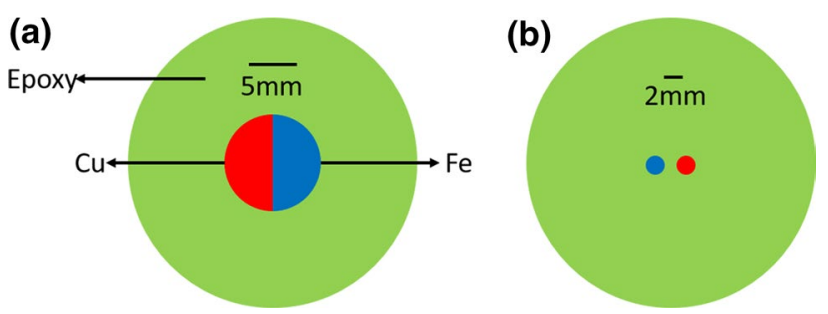

Fig. 1 Schematics of top view of the galvanic couple electrode wrapped by epoxy resin: a electrochemical test, b SVET test
Table 1 Chemical composition (mass\%) of the drawn steel 20 used in this work

\begin{tabular}{lllllllll}
\hline $\mathrm{C}$ & $\mathrm{Si}$ & $\mathrm{Mn}$ & $\mathrm{S}$ & $\mathrm{P}$ & $\mathrm{Cr}$ & $\mathrm{Ni}$ & $\mathrm{Cu}$ & $\mathrm{Fe}$ \\
\hline 0.20 & 0.21 & 0.43 & 0.020 & 0.023 & 0.17 & 0.21 & 0.12 & Bal. \\
\hline
\end{tabular}


The samples were ground to 2000 grit successively using silicon carbide ( $\mathrm{SiC}$ ) sheets. Then the surface of the sample was polished by diamond paste, finally degreased with acetone and cleaned with pure water prior to various tests.

The simulated solution was based on acidic red soil in Fuzhou, Fujian Province in the southeastern part of China. The reagents used in the experiments are analytical reagent. The composition of solution is listed in Table 2. The simulated solution was aerated.

\subsection{Electrochemical Test}

The electrochemical test used a traditional three-electrode system in which a saturated calomel electrode (SCE), a Pt net and copper-drawn steel were used as reference electrode, counter electrode and working electrode, respectively. Electrochemical tests such as the open-circuit potential (OCP) and polarization curve were carried out by using an electrochemical workstation (Interface-5000, Gramy, USA). The samples were immersed into the simulated solution for $24 \mathrm{~h}$ to keep OCP stable before the potentiodynamic polarization test. The potentiodynamic polarization tests for copper were carried out at a scanning rate of $0.1667 \mathrm{mV} / \mathrm{s}$ from -1.2 to $0.6 \mathrm{~V}$ versus OCP. The potentiodynamic polarization tests for steel and $\mathrm{Cu}-\mathrm{Fe} \mathrm{GC}$ were carried out at a scanning rate of $0.1667 \mathrm{mV} / \mathrm{s}$ from -0.6 to $0.6 \mathrm{~V}$ versus OCP.

The zero resistance ammeter (ZRA, CST520, CORRTEST, China) was employed to measure the galvanic current density between $\mathrm{Cu}$ and drawn steel 20 in the simulated solution with different $\mathrm{pH}$ values. The galvanic current test was conducted with $\mathrm{Cu}$ and drawn steel 20 as the working electrode and a saturated calomel electrode (SCE) as the reference electrode. All the electrochemical tests were performed at room temperature $\left(25 \pm 1^{\circ} \mathrm{C}\right)$ with natural ventilation, and all the electrochemical tests were carried out at least three times to ensure the date repeatability.

\subsection{Immersion Test and SVET Measurement}

The simulated solutions used in the immersion tests were exactly the same as those described in Sect. 2.1. Prior to the starting of the immersion test, the four sides of sample were covered with an epoxy resin to reduce the experimental error and the circle surface $(1 \mathrm{~cm}$ in diameter) was exposed in the simulated solution with different $\mathrm{pH}$ values. The immersion test was carried out at $25{ }^{\circ} \mathrm{C}$ for $48 \mathrm{~h}$. After the immersion tests, some specimens were washed with pure water and alcohol, and then dried in a vacuum-drying box at $50{ }^{\circ} \mathrm{C}$ for $12 \mathrm{~h}$.

Table 2 Chemical composition $(\mathrm{g} / \mathrm{L})$ of the solution in this work
These samples were used for SEM surface observation. The other specimens were packed in epoxy resin and polished after being cut with a saw blade for cross-sectional observation. The JEOL JSM-7800F scanning electron microscope (SEM) was employed to characterize the morphologies of the $\mathrm{Cu}-\mathrm{Fe} \mathrm{GC}$ after immersion tests. After the immersion test, the rusts from the surface of the steel were collected and characterized via a LabRAM HR Evolution (Raman).

The weight loss experiment was divided into two groups. One group was drawn steel 20 without coupling with copper, and the other group was drawn steel 20 coupling with copper. Before sealing with the epoxy resin, the drawn steel 20 and copper were degreased with acetone, then cleaned by absolute alcohol and washed by double-distilled water; after that, the cleaned samples were dried in the vacuum-drying box and the weight of drawn steel 20 was recorded. The samples were immersed into the simulated solution at $25^{\circ} \mathrm{C}$ for $48 \mathrm{~h}$. After that, the samples were immersed into acidic solution $(0.025 \mathrm{~mol} / \mathrm{L}$ urotropine, $6.0 \mathrm{~mol} / \mathrm{L} \mathrm{HCl})$ for $10 \mathrm{~min}$ to remove the corrosion product. Then, the specimens were washed with absolute alcohol and distilled water followed by drying in oven. To calculate the water absorption of the epoxy resin, the epoxy resin with the same size of the sample was immersed in the simulated solution. The mass change of the epoxy resin was calculated at each experimental period to eliminate the error caused by this factor. All samples were weighed via a balance with a precision of $0.1 \mathrm{mg}$.

The SVET was performed by VersaSCAN electrochemical scanning system (Princeton, AMETEK, USA). The samples for SVET tests were prepared as follows. After polishing and cleaning, the polishing surface of sample was placed horizontally with facing upwards. Then the sides of samples were wrapped by tape to keep the electrolyte from leaking.

In the SVET tests, it used the platinum probe with a diameter of about $20 \mu \mathrm{m}$ and vibrates in a plane perpendicular to the sample at an amplitude of $20 \mu \mathrm{m}$ and a frequency of $80 \mathrm{~Hz}$. The scan was done $50 \mu \mathrm{m}$ away from substrate of the sample. The size of the ion current diagram was $2.5 \mathrm{~mm} \times 5.5 \mathrm{~mm}$, and the area for imaging of the sample in each experiment was $13.75 \mathrm{~mm}^{2}$. The scanning rate is $100 \mu \mathrm{m} / \mathrm{s}$. During the scanning, the reference measurement of the microelectrode away from the active area was subtracted from the measurement.

\section{Result and Discussion}

\subsection{Open-Circuit Potential}

Figure 2 shows the open-circuit potential of the copper, drawn steel 20 and $\mathrm{Cu}-\mathrm{Fe}$ GC in the simulated solution with time. The OCP of the copper increases from -58 to $-10 \mathrm{mV}$ with increasing solution $\mathrm{pH}$ from 2.4 to 6 . The OCP of the

\begin{tabular}{lll}
\hline $\mathrm{NaCl}$ & $\mathrm{Na}_{2} \mathrm{SO}_{4}$ & $\mathrm{NaHCO}_{3}$ \\
\hline 0.138 & 0.08 & 0.014 \\
\hline
\end{tabular}


drawn steel 20 decreases from -500 to $-635 \mathrm{mV}$ with increasing solution $\mathrm{pH}$ value from 2.4 to 6 . The galvanic couple potential (GCP) for $\mathrm{Cu}-\mathrm{Fe}$ GC decreased from -505 to $-627 \mathrm{mV}$ as the $\mathrm{pH}$ increased from 2.4 to 6 . From the above experiment, the electrode potential of copper is clearly higher than that of drawn steel 20 in the simulated solution. Generally speaking, the material with a low electrode potential acted as the anode and the material with a high electrode potential acted as the cathode in the galvanic couple [46]. The GCP of the $\mathrm{Cu}-\mathrm{Fe}$ GC is close to the OCP of the drawn steel 20 electrode, indicating that the copper electrode is only used as the supporter of the cathode process.

Figure 2a shows that the OCP of copper oscillates in the solution with $\mathrm{pH} 2.4$ and 4.4. The change of solution $\mathrm{pH}$ significantly influences on the corrosion behavior of copper. In an acidic solution, the oxidation layer on the substrate of copper will be formed and degraded. The OCP of copper in the solution with $\mathrm{pH} 4.4$ starts to oscillate at $12 \mathrm{~h}$, until then the OCP keeps steady. When the oxide layer on the copper surface is destroyed, a new oxide layer will be formed. This process of formation and degradation of the oxide layer causes fluctuations of OCP in the curve. The variation ranges of the OCP for copper and drawn steel 20 are about $48 \mathrm{mV}$ and $135 \mathrm{mV}$ in the simulated solution with different $\mathrm{pH}$ values. Obviously, the change in $\mathrm{pH}$ has a more significant effect on the OCP of drawn steel 20 than that of the copper. For drawn steel 20 electrode at $\mathrm{pH} 2.4$, the control process is a cathode process due to the active state of the drawn steel 20 , and the OCP is very stable. When $\mathrm{pH}$ is higher than 2.4, a deposition layer forms on the substrate of the drawn steel 20 to inhibit the corrosion process, and the control process is gradually transformed into the anode control. Because the oxide layer on the electrode surface is unstable, the OCP gradually moves negatively and is accompanied by oscillation $[18,44,47]$.

\subsection{Electrochemical Test}

Figure 3 shows the potentiodynamic polarization curves of copper, drawn steel 20 and $\mathrm{Cu}-\mathrm{Fe}$ GC in the simulated solution with different $\mathrm{pH}$ values. As shown in Fig. 3, the anodic polarization curves of the copper are similar without notable change with different $\mathrm{pH}$ values, while the cathodic polarization curve changes obviously at $\mathrm{pH} 2.4$, which changes the cathode process from dissolved oxygen reduction to hydrogen evolution process with the negative shift of applied polarization. For drawn steel 20, it is clear that the electrode reaction of the cathode process changes from oxygen diffusion process to hydrogen evolution process with the decrease in $\mathrm{pH}$, and the corrosion is accelerated significantly at $\mathrm{pH}$
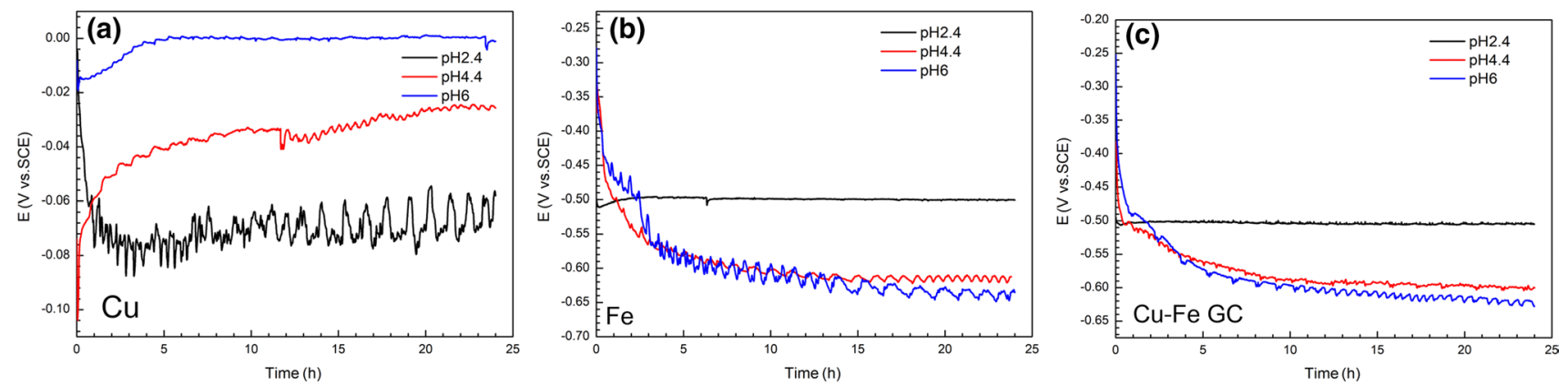

Fig. 2 OCP curves as a function of time in simulated solution with different $\mathrm{pH}$ values for: a $\mathrm{Cu}, \mathbf{b} \mathrm{Fe}, \mathbf{c} \mathrm{Cu}-\mathrm{Fe} \mathrm{GC}$
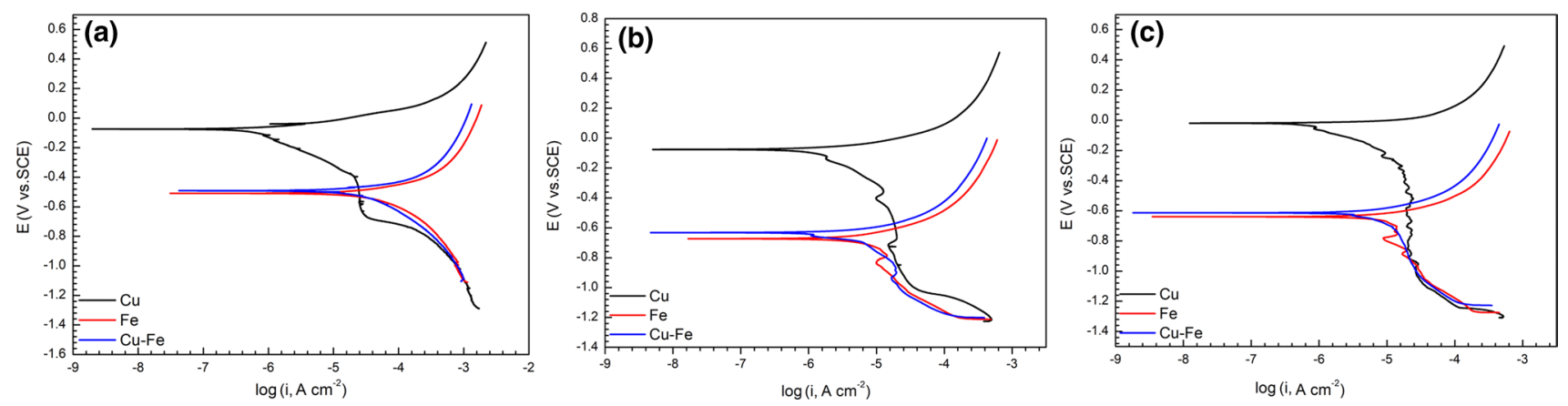

Fig. 3 Polarization curves for: $\mathrm{Cu}, \mathrm{Fe}$ and $\mathrm{Cu}-\mathrm{Fe} \mathrm{GC}$ immersed in the solution with different $\mathrm{pH}$ values: $\mathbf{a} \mathrm{pH}=2.4, \mathbf{b} \mathrm{pH}=4.4, \mathbf{c} \mathrm{pH}=6$ at a scanning rate of $0.1667 \mathrm{mV} / \mathrm{s}$ 
2.4. For $\mathrm{Cu}-\mathrm{Fe} \mathrm{GC}$, the cathode branch of the polarization curve is similar to that for drawn steel 20.

As shown in Fig. 3, the cathodic branch of the polarization curve for copper intersects the anodic branch of the polarization curve for drawn steel 20. Moreover, the intersection lies in the oxygen reduction region of the cathodic branch of the copper in simulated solution, which indicates that oxygen reduction occurs as the cathodic process in the corrosion of the $\mathrm{Cu}-\mathrm{Fe} \mathrm{GC}$. The anodic reaction from the polarization for $\mathrm{Cu}-\mathrm{Fe}$ GC almost coincides with that of drawn steel 20.

Figure 4 displays the galvanic current of the $\mathrm{Cu}-\mathrm{Fe}$ GC immersed in the simulated solution with different $\mathrm{pH}$ values. The negative current denotes electrons flow from drawn steel 20 to copper. With copper connected electrically to drawn steel 20, as the electrode potential of copper in the simulated solution is higher than that of drawn steel 20 , the corrosion rate of the drawn steel 20 increases drastically. As shown in Fig. 4, pH decreases from 6 to 2.4, and the galvanic current of $\mathrm{Cu}-\mathrm{Fe}$ GC increases from 20 to $35 \mu \mathrm{A} / \mathrm{cm}^{2}$ (integral average value). The galvanic current of $\mathrm{Cu}-\mathrm{Fe} \mathrm{GC}$ is maximum at $\mathrm{pH}$ 2.4. It indicates that the galvanic corrosion rate of the $\mathrm{Cu}-\mathrm{Fe} \mathrm{GC}$ at $\mathrm{pH} 2.4$ is higher than that at $\mathrm{pH} 4.4$ and 6.

Figure 5 shows the weight loss of drawn steel 20 coupling with the copper and without coupling with the copper in the simulated solution with different $\mathrm{pH}$ values. The corrosion of drawn steel 20 becomes more serious with the decrease in the $\mathrm{pH}$. While the weight loss of drawn steel 20 increases after coupling with the copper, this reveals that the corrosion of drawn steel 20 is greatly accelerated by coupling with the copper.

The self-corrosion might happen on the steel, while the galvanic corrosion occurs after being coupled with the copper. Galvanic effect $\gamma$ is usually used to characterize the effect of coupling on the corrosion behavior of materials $[48,49]$. When only the dissolution reaction occurs on the anode of the metal, the galvanic effect $\gamma$ can be calculated by the following equation:

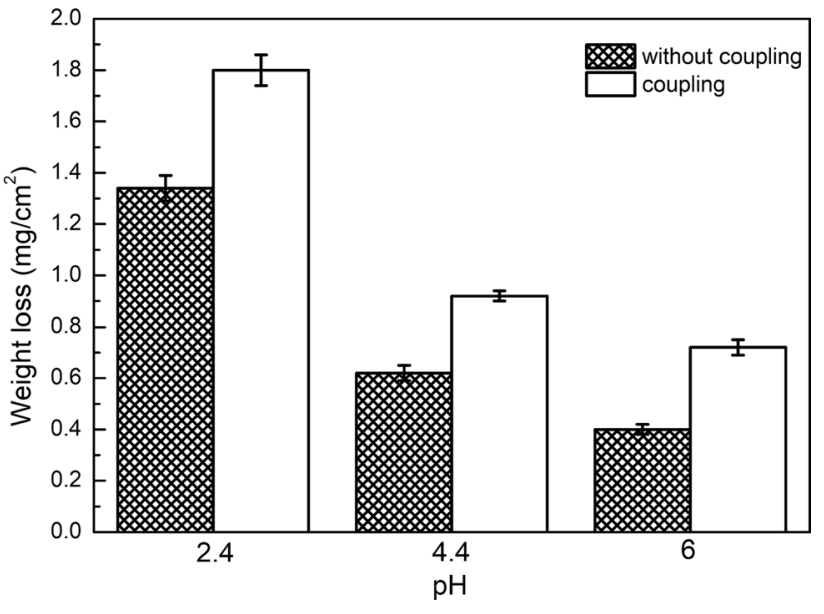

Fig. 5 Weight loss of drawn steel 20 in the simulated solution with different $\mathrm{pH}$ values for $48 \mathrm{~h}$

$\gamma=\frac{i_{\mathrm{A}}^{\prime}}{i_{\mathrm{A}}}=\frac{i_{\mathrm{g}}+\left|i_{\mathrm{A}_{\mathrm{c}}}\right|}{i_{\mathrm{A}}} \approx \frac{i_{\mathrm{g}}}{i_{\mathrm{A}}}$.

At the same time, the galvanic effect can also be calculated according to the weight loss of the immersion test:

$\gamma=\frac{i_{\mathrm{A}}^{\prime}}{i_{\mathrm{A}}}=\frac{i_{\mathrm{g}}+\left|i_{\mathrm{A}_{\mathrm{c}}}\right|}{i_{\mathrm{A}}}=\frac{\Delta W_{\mathrm{A}}^{\prime}}{\Delta W_{\mathrm{A}}}$.

In the formula, $i_{\mathrm{A}}$ is the corrosion current of the metal $\mathrm{A}$, $i_{\mathrm{A}}^{\prime}$ is the anode corrosion current after coupling, $i_{\mathrm{g}}$ is the galvanic current, $i_{\mathrm{A}_{\mathrm{c}}}$ is the cathodic current on the metal $\mathrm{A}$, and $\Delta W_{\mathrm{A}}$ and $\Delta W_{\mathrm{A}}^{\prime}$ are the weight loss of anode material before and after coupling, respectively. When only the dissolution reaction occurs on the anode of the metal, $i_{\mathrm{A}_{\mathrm{c}}}$ is almost zero, $i_{\mathrm{g}}$ is the value of the average galvanic curves density in the experimental period $(24 \mathrm{~h})$, and $i_{\mathrm{g}}(t)$ within $24 \mathrm{~h}$ is integrated and averaged. The calculation formula is given as follows [50]:
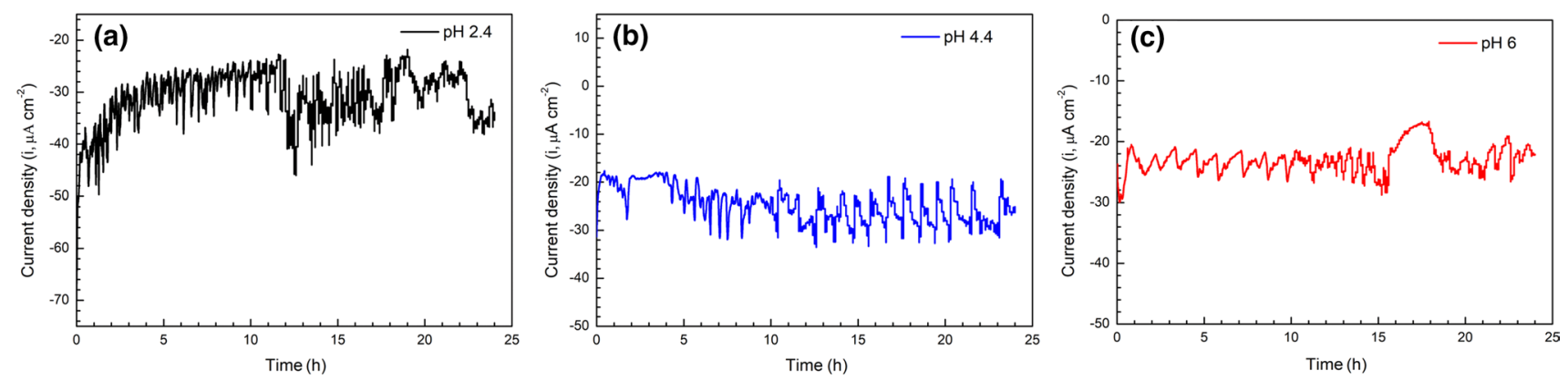

Fig. 4 Galvanic curves density of the $\mathrm{Cu}-\mathrm{Fe} \mathrm{GC}$ immersed in the solution with: $\mathbf{a} \mathrm{pH}=2.4, \mathbf{b} \mathrm{pH}=4.4, \mathbf{c} \mathrm{pH}=6$. The galvanic curve densities calculated by formula (3) are a $35.7232 \mu \mathrm{A} / \mathrm{cm}^{2}$, b $23.5919 \mu \mathrm{A} / \mathrm{cm}^{2}, \mathbf{c} 20.8616 \mu \mathrm{A} / \mathrm{cm}^{2}$ 
Table 3 Galvanic effect of drawn steel 20 calculated by two methods

\begin{tabular}{llll}
\hline $\mathrm{pH}$ & $\begin{array}{l}\text { Electrochemical } \\
\text { process }\left(\gamma_{1}\right)\end{array}$ & $\begin{array}{l}\text { Weight loss } \\
\text { method }\left(\gamma_{2}\right)\end{array}$ & $\begin{array}{l}\text { Ratio between } \\
\text { the two methods } \\
\left(\gamma_{1} / \gamma_{2}\right)\end{array}$ \\
\hline 2.4 & 0.3253094 & 1.34328 & 0.2421754 \\
4.4 & 1.478432 & 1.48387 & 0.99633 \\
6 & 1.739559 & 1.8 & 0.96642162 \\
\hline
\end{tabular}

$i_{\mathrm{g}}=\frac{I_{\mathrm{g}}}{S_{\mathrm{A}}}=\frac{1}{S_{\mathrm{A}} T} \int_{0}^{T} I_{\mathrm{g}}(t) \mathrm{d} t$.

The data in Table 3 are obtained through calculation, and $\gamma_{1}$ and $\gamma_{2}$ are the galvanic effect calculated by electrochemical process and weight loss method, respectively. Table 3 shows that $\gamma_{1}$ and $\gamma_{2}$ increase as the $\mathrm{pH}$ increases, and both $\gamma_{1}$ and $\gamma_{2}$ are greater than 1 when their $\mathrm{pH}$ values are 4.4 and 6 . When $\mathrm{pH}$ is $2.4, \gamma_{1}$ and $\gamma_{2}$ have a large deviation. This means that the condition of Formula (1) is not satisfied. At pH 2.4, not only the drawn steel 20 in galvanic couple is dissolved, but also the cathode reaction is carried out at a certain speed.

According to the study of Mansfeld [48], the relationship between the anode dissolution current and galvanic current is as follows:

$\frac{I_{\mathrm{g}}}{I_{\mathrm{d}}}=1-\exp \left[-\frac{\left(b_{\mathrm{a}}+b_{\mathrm{c}}\right)}{0.434 b_{\mathrm{a}} b_{\mathrm{c}}}\left(\emptyset_{\mathrm{g}}-\emptyset_{\text {corr }}\right)\right]$.

In Formula (4), $b_{\mathrm{a}}$ and $b_{\mathrm{c}}$ are the Tafel slope for cathodic reaction on metal $\mathrm{A}$ and $\mathrm{C} . E_{\mathrm{g}}$ is the galvanic potential and $E_{\text {corr }}$ is the corrosion potential of uncoupled metal. From Formula (4), it shows that when the polarization is large, $E_{\mathrm{g}} \gg E_{\text {corr }}$, the galvanic current $\left(I_{\mathrm{g}}\right)$ is nearly equal to the dissolution current $\left(I_{\mathrm{d}}\right)$, However, when the polarization is small, $E_{\mathrm{g}} \approx E_{\text {corr }}$, it can be inferred that:

$I_{\mathrm{g}}=I_{\mathrm{d}}-I_{\text {corr }} \exp \left(-\frac{E_{\mathrm{g}}-E_{\text {corr }}}{0.434 b_{\mathrm{c}}}\right) \approx I_{\mathrm{d}}-I_{\text {corr }}$.

Therefore, when polarization is very small, the galvanic current is the value added in the anode dissolution current of the anode metal after coupling:

$\gamma=\frac{I_{\mathrm{A}}^{\prime}}{I_{\mathrm{A}}}=\frac{I_{\mathrm{g}}+I_{\text {corr }}}{I_{\text {corr }}}=1+\frac{I_{\mathrm{g}}}{I_{\text {corr }}}$.

Figure 6 shows the potential of drawn steel 20 and galvanic couple in the simulated solution with different $\mathrm{pH}$ values. In the solution with $\mathrm{pH} 2.4$, drawn steel 20 has little polarization after coupling. It satisfies Formulas (5) and (6). The galvanic effect $\left(\gamma_{1}\right)$ calculated from Formula (6) is 1.3253 . It is closer to the data obtained from the weight loss experiment.
This indicates that coupling accelerates the corrosion of drawn steel 20 and the galvanic effect in acid solution is lower than that in neutral solution. Furthermore, only the metal dissolution occurs in the anode at $\mathrm{pH} 4.4$ and 6. As can be seen, with the increase in $\mathrm{pH}$, the corrosion rate of galvanic couple decreases, while the galvanic effect increases.

\subsection{Raman Spectroscopy of Rusts}

The corrosion rate of the drawn steel 20 is related not only to the solution $\mathrm{pH}$, but also to the composition and structure of rust formed on the substrate of drawn steel 20. Figure 7 shows the Raman spectra of rust collected from the different samples after immersion test. The corrosion products in rust are made of $\mathrm{FeO}, \mathrm{Fe}_{3} \mathrm{O}_{4}, \alpha-\mathrm{Fe}_{2} \mathrm{O}_{3}$ (hematite), $\gamma$ - $\mathrm{Fe}_{2} \mathrm{O}_{3}$ (maghemite), $\alpha$-FeOOH (goethite), $\beta$-FeOOH (akaganeite), $\gamma$-FeOOH (lepidocrocite), $\delta$-FeOOH (feroxyhite), etc. $\gamma$-FeOOH and $\delta$-FeOOH are unstable and will be further converted into other stable oxide. However, other oxides such as $\gamma-\mathrm{Fe}_{2} \mathrm{O}_{3}$ and $\alpha-\mathrm{FeOOH}$ are stable and have compact forms [51]. In Fig. 7, the main composition of the rust is $\gamma$-FeOOH at $\mathrm{pH}$ 6. It cannot form the compact protective film with strong adhesion. The conversion rate from active $\gamma$-FeOOH to stable $\alpha$-FeOOH and $\mathrm{Fe}_{2} \mathrm{O}_{3}$ depends on the difference in $\mathrm{pH}$. The increasing acidity in the solution makes the transformation of $\gamma-\mathrm{FeOOH}$ faster. At $\mathrm{pH} 4.4$, the main compositions of the rust are $\alpha-\mathrm{Fe}_{2} \mathrm{O}_{3}$ and $\gamma$ - $\mathrm{FeOOH}[52,53]$. The main compositions of the rust are $\alpha-\mathrm{FeOOH}, \alpha-\mathrm{Fe}_{2} \mathrm{O}_{3}$, $\gamma-\mathrm{Fe}_{2} \mathrm{O}_{3}$ and $\gamma-\mathrm{FeOOH}$ at $\mathrm{pH}$ 2.4. Although the corrosion products on the surface of drawn steel 20 are stable at $\mathrm{pH}$ 2.4 , the protective layer on the surface is incomplete due to the low $\mathrm{pH}$ of the simulated solution, which provides conditions for pitting corrosion.

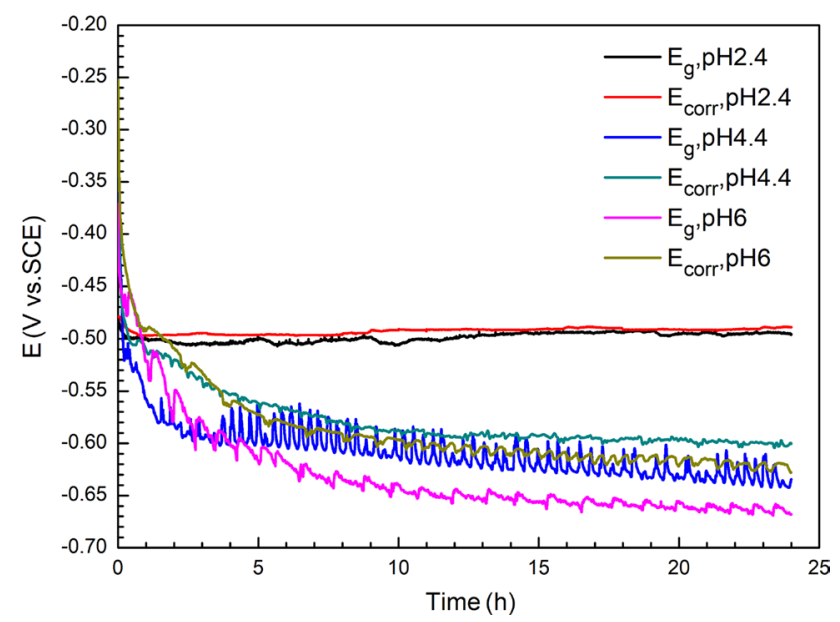

Fig. 6 Relationships between the potential of the drawn steel 20 without coupling with copper and $\mathrm{Cu}-\mathrm{Fe} \mathrm{GC}$ and time in the solution with different $\mathrm{pH}$ values 

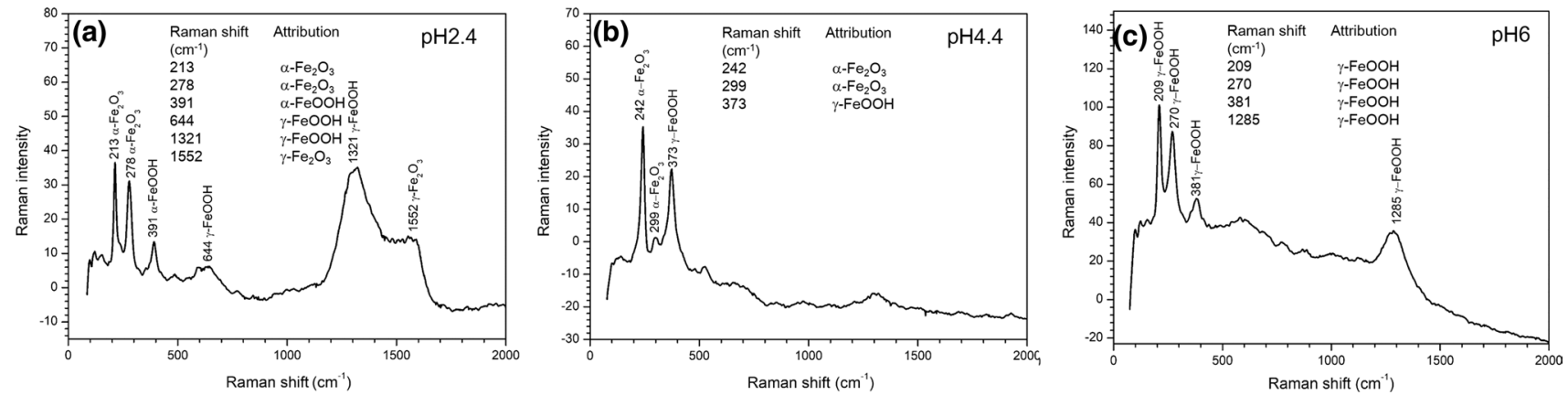

Fig. 7 Raman spectra of rust formed on drawn steel 20 coupled with copper immersed in the simulated solution with: $\mathbf{a} \mathrm{pH}=2.4, \mathbf{b} \mathrm{pH}=4.4, \mathbf{c}$ $\mathrm{pH}=6$

The $\gamma$-FeOOH exhibits two transformation modes: One is to convert into $\alpha-\mathrm{FeOOH}$ (hexagonally close-packed), and the other is related to the dehydration of $\gamma-\mathrm{FeOOH}$ to $\gamma-\mathrm{Fe}_{2} \mathrm{O}_{3}$. And then $\gamma-\mathrm{Fe}_{2} \mathrm{O}_{3}$ is transformed into $\alpha-\mathrm{Fe}_{2} \mathrm{O}_{3}$, which is one of the most stable iron oxides $[54,55]$. Due to the pores morphology of the $\gamma$-FeOOH, when $\gamma$-FeOOH formed on the substrate of drawn steel 20, the dissolved oxygen further penetrates and new $\gamma$-FeOOH is generated continuously. It is consistent with the result obtained by the open-circuit potential in Sect. 3.1.

\subsection{SVET and Corrosion Morphology}

Figure 8 shows ion current density distribution on the surface of the $\mathrm{Cu}-\mathrm{Fe} \mathrm{GC}$ as a function of position in the simulated solution with different $\mathrm{pH}$ values. When the copper and drawn steel 20 are galvanically coupled and exposed to solution, ionic currents flow through the electrolyte between the electrodes. Figure 8 shows that two relative circular peaks appear in the ionic current maps. There are two regions with different electrochemical activities in the position of the two wires. The flux of positive ion current and negative ion current is distributed over the steel and copper separately. According to Eq. (7), the positive current derives from the flux of $\mathrm{Fe}^{2+}$ ions released from the drawn steel 20 surface during the metal oxidation process.

$\mathrm{Fe} \rightarrow \mathrm{Fe}^{2+}+2 \mathrm{e}^{-}$.

Homoplastically, the negative current measured above copper is due to the flux of hydroxide ions on the metal surface due to the reduction of dissolved oxygen and hydrogen evolution reaction:

$\mathrm{O}_{2}+2 \mathrm{H}_{2} \mathrm{O}+4 \mathrm{e}^{-} \rightarrow 4 \mathrm{OH}^{-}$

$2 \mathrm{H}^{+}+2 \mathrm{e}^{-} \rightarrow \mathrm{H}_{2}$.
As shown in Fig. 8, the drawn steel 20 is anode when coupled with copper in the simulated solution with different pH values. In Fig. 8, the positive peak of ion current density is $400 \mu \mathrm{A} \mathrm{cm}^{-2}$ at $\mathrm{pH} 2.4$. When the $\mathrm{pH}$ is 4.4 , the maximum positive ion current density is $369 \mu \mathrm{A} \mathrm{cm}^{-2}$. And at $\mathrm{pH} 6$, the maximum positive ion current density is $276 \mu \mathrm{A} \mathrm{cm} \mathrm{cm}^{-2}$. As shown in Fig. 8, the amount of $\mathrm{Fe}^{2+}$ on the surface of the drawn steel electrode is less with the increase in $\mathrm{pH}$. In the electric field formed by $\mathrm{Cu}-\mathrm{Fe} \mathrm{GC}$, the dissolved iron ions migrate away from the surface of drawn steel 20 to that of copper electrode and then undergo hydrolysis at $\mathrm{pH}$ 6. It makes the corrosion products accumulate at the junction of $\mathrm{Cu}-\mathrm{Fe} \mathrm{GC}$. This keeps the dissolved active zone of the substrate of the steel electrode away from the copper electrode (Fig. 8c), which also increases the solution resistance of $\mathrm{Cu}-\mathrm{Fe}$ couple and reduces the corrosion rate of the $\mathrm{Cu}-\mathrm{Fe} \mathrm{GC}$.

Figure 9 shows the metallographic structure of drawn steel 20. It can be seen that the cross-sectional structure of the cold-drawn steel consists of ferrite and pearlite. The sheetlike cementite and ferrite with large potential difference in pearlite are easy to form micro-corrosion cell, so the pearlite in the substrate of drawn steel 20 is corroded preferentially, which provides conditions for subsequent pitting corrosion.

From the longitudinal section structure of the cold-drawn steel (Fig. 9c, d), the structure of pearlite is vimineous along the drawing direction. The vimineous pearlite corrodes preferentially, which forms the deep corrosion pore.

The SEM morphologies of the $\mathrm{Cu}-\mathrm{Fe}$ GC immersed in the simulated solution with different $\mathrm{pH}$ values for $48 \mathrm{~h}$ are shown in Fig. 10. It is clear that the corrosion products on the surface of the drawn steel 20 have different states with different $\mathrm{pH}$ values (Fig. 10a-c). The corrosion products in the solution with $\mathrm{pH} 6$ exhibit the pores morphology. When $\mathrm{pH}$ is 4.4 and 2.4 , there are fewer pores on the corrosion product. In Sect. 3.3, the corrosion products are mainly made of $\gamma$-FeOOH with pores morphology in $\mathrm{pH}$. As the $\mathrm{pH}$ 

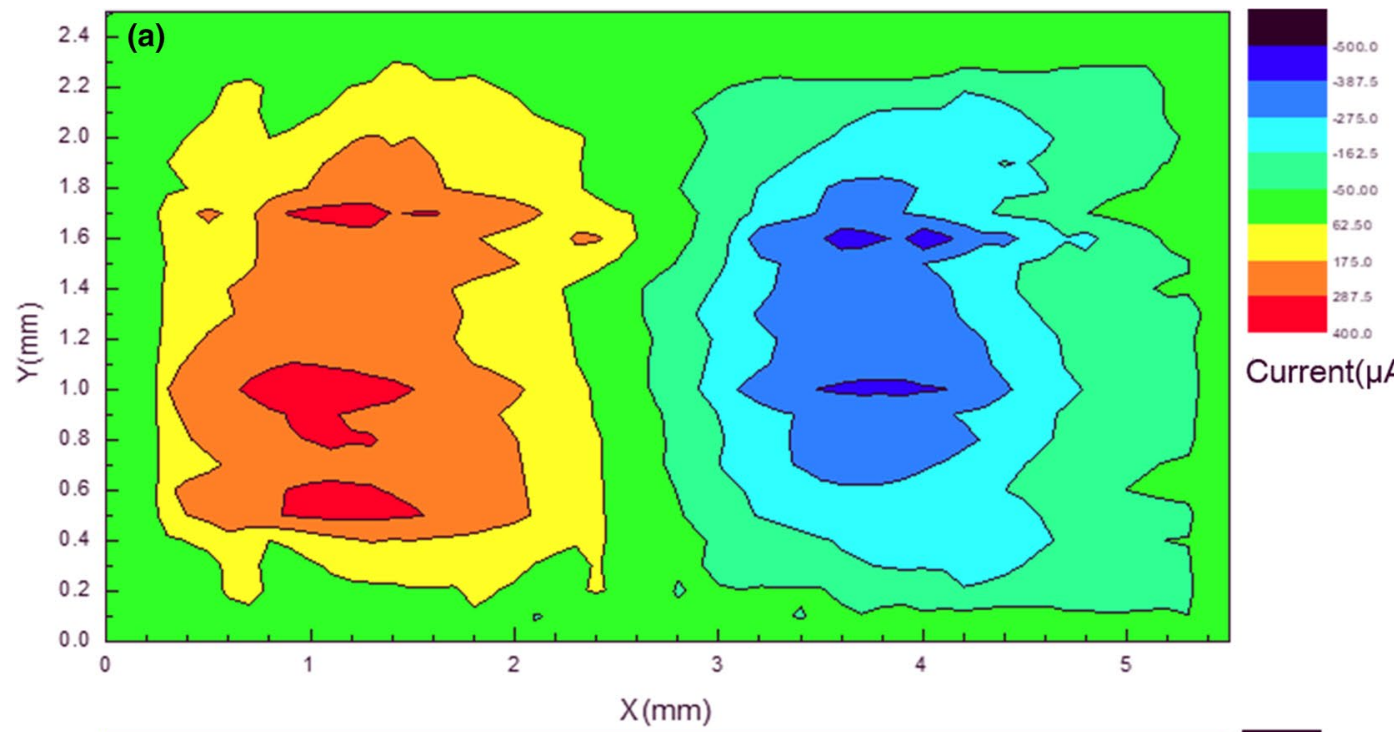

\section{Current $(\mu \mathrm{A} \mathrm{cm}-2)$}
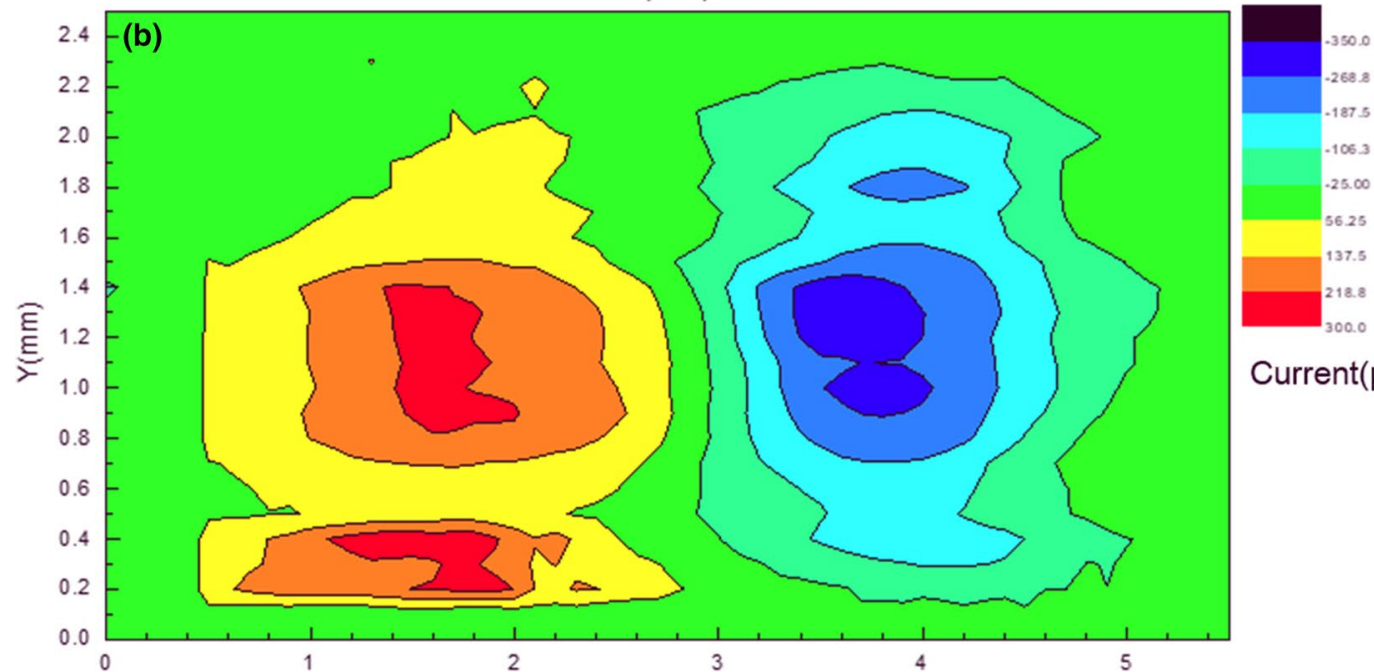

Current $(\mu \mathrm{A} \mathrm{cm}-2)$
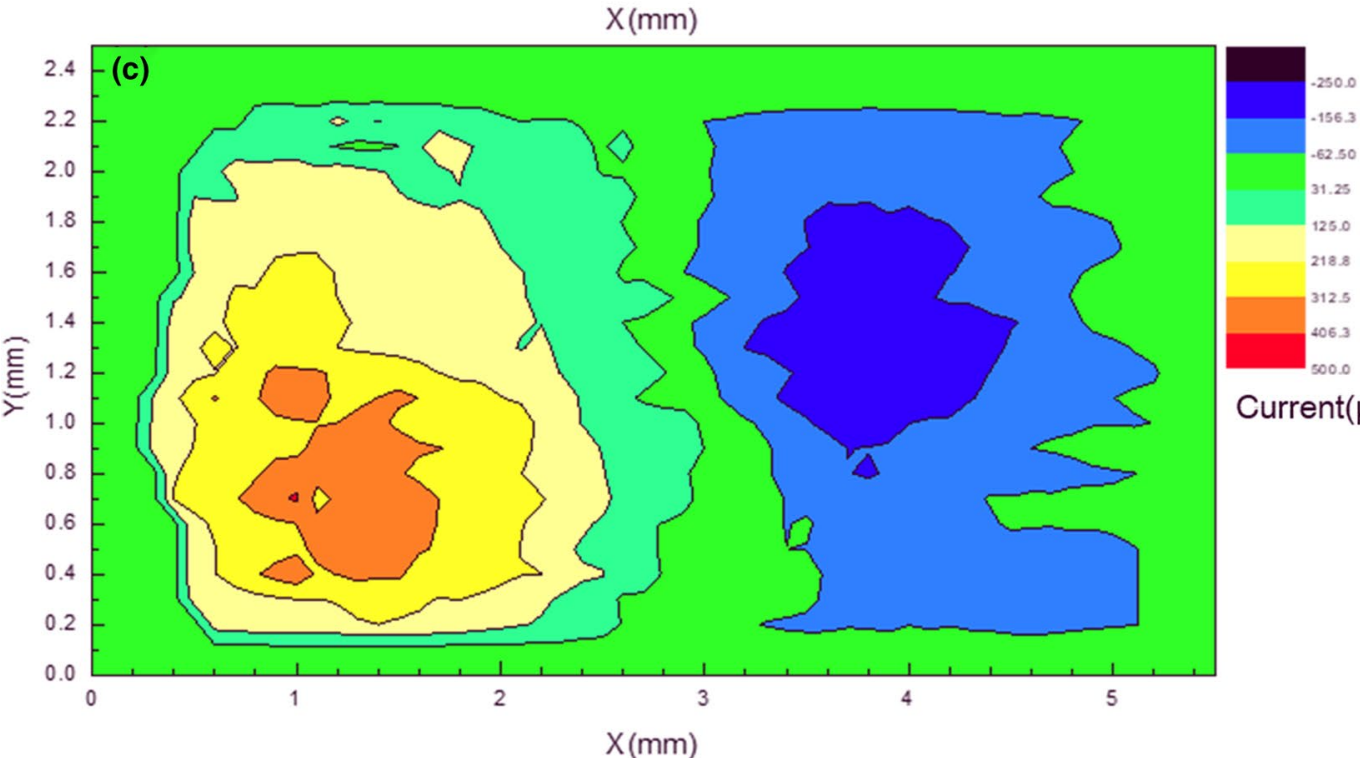

Current $(\mu \mathrm{A} \mathrm{cm}-2)$

Fig. 8 Ionic current maps determined above the $\mathrm{Cu}-\mathrm{Fe} \mathrm{GC}$ immersed in the simulated solution with: $\mathbf{a} \mathrm{pH}=2.4, \mathbf{b} \mathrm{pH}=4.4$, $\mathbf{c} \mathrm{pH}=6$. The left side is drawn steel 20 electrode, and the right side is copper electrode 

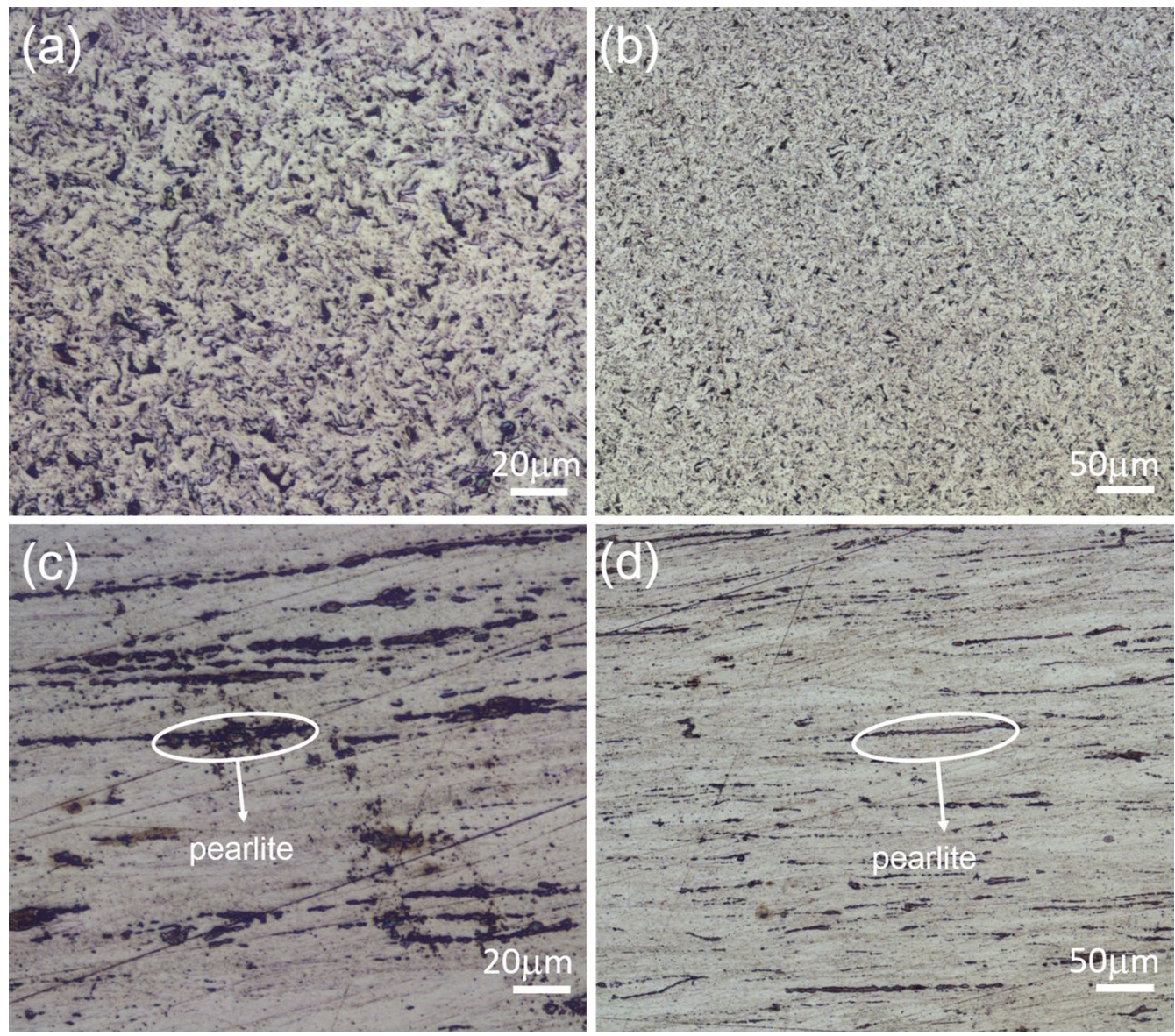

Fig. 9 Metallographic structure of cold-drawn steel: a crosswise (partial enlargement of $\mathbf{b}$ ), $\mathbf{b}$ crosswise, $\mathbf{c}$ longitudinal (partial enlargement of d), d longitudinal

decreases, $\gamma$-FeOOH transforms into $\alpha-\mathrm{FeOOH}$ and $\mathrm{Fe}_{2} \mathrm{O}_{3}$. When $\mathrm{pH}$ is 2.4 , the main component of the corrosion products is stable.

The corrosion behavior of $\mathrm{Cu}-\mathrm{Fe} \mathrm{GC}$ can be further analyzed from the SEM images of the cross section of drawn steel 20 (Fig. 10d-f). When $\mathrm{pH}$ is 2.4 and 4.4, there are corrosion products $\alpha-\mathrm{FeOOH}, \alpha-\mathrm{Fe}_{2} \mathrm{O}_{3}, \gamma-\mathrm{Fe}_{2} \mathrm{O}_{3}$ and $\gamma$-FeOOH on the surface of drawn steel 20 (Fig. 10a, b), but $\gamma-\mathrm{FeOOH}$ is unstable and poor adhesivity; therefore, the corrosion product layer is incomplete. With $\mathrm{pH}$ of 6 , there are less corrosion products on the surface of drawn steel 20, because the corrosion product on the surface of the sample is $\gamma-\mathrm{FeOOH}$, which is unstable and of poor adhesivity. Figure 10d-f shows that the depth of the corrosion hole is about $100 \mu \mathrm{m}$ at $\mathrm{pH} 2.4$ and $60 \mu \mathrm{m}$ at $\mathrm{pH} 4.4$. At pH 6, the depth of the corrosion hole is about $10 \mu \mathrm{m}$. When the $\mathrm{pH}$ is 2.4 , the width of the etched hole is about $10 \mu \mathrm{m}$, and the width of the corrosion hole is wide in the middle and both ends are fine. As shown Fig. 10c, the corrosion hole is relatively dense. When the $\mathrm{pH}$ is 6 , the corrosion holes are sparse and thin. As discussed above, perlite is corroded in the depth in substrate; meanwhile, the $\mathrm{H}^{+}$and $\mathrm{Fe}^{2+}$ migrate to the copper electrode under the action of the electric field formed by copper and steel. In acidic environment, the quantity of $\mathrm{H}^{+}$and $\mathrm{Fe}^{2+}$ migration is relatively large; therefore, there is no deposition near the corrosion hole. The hydrolysis of $\mathrm{Fe}^{2+}$ in corrosion hole enhances the acidity in the corrosion hole, which accelerates dissolution of vimineous pearlite in the hole (Fig. 10d, e). In the neutral environment, the initial dissolved $\mathrm{Fe}^{2+}$ hydrolyzes on the surface immediately, and some $\mathrm{Fe}^{2+}$ transfer to the cathode under the action of electric field. In this way, it only accelerates the corrosion rate of the whole electrode, and it cannot form pitting corrosion (Fig. 10f).

The SEM images of the drawn steel 20 without coupling with copper after immersing in the simulated solution with different $\mathrm{pH}$ values for $48 \mathrm{~h}$ are shown in Fig. 11. The corrosion products of drawn steel 20 change from the continuous oxide layer (Fig. 11a) to the pore morphology (Fig. 11c). This is related to the conversion of iron oxides at different $\mathrm{pH}$ values. Moreover, the depth of the corrosion hole is small. Compared with Fig. 10, the effect of the galvanic corrosion may be 

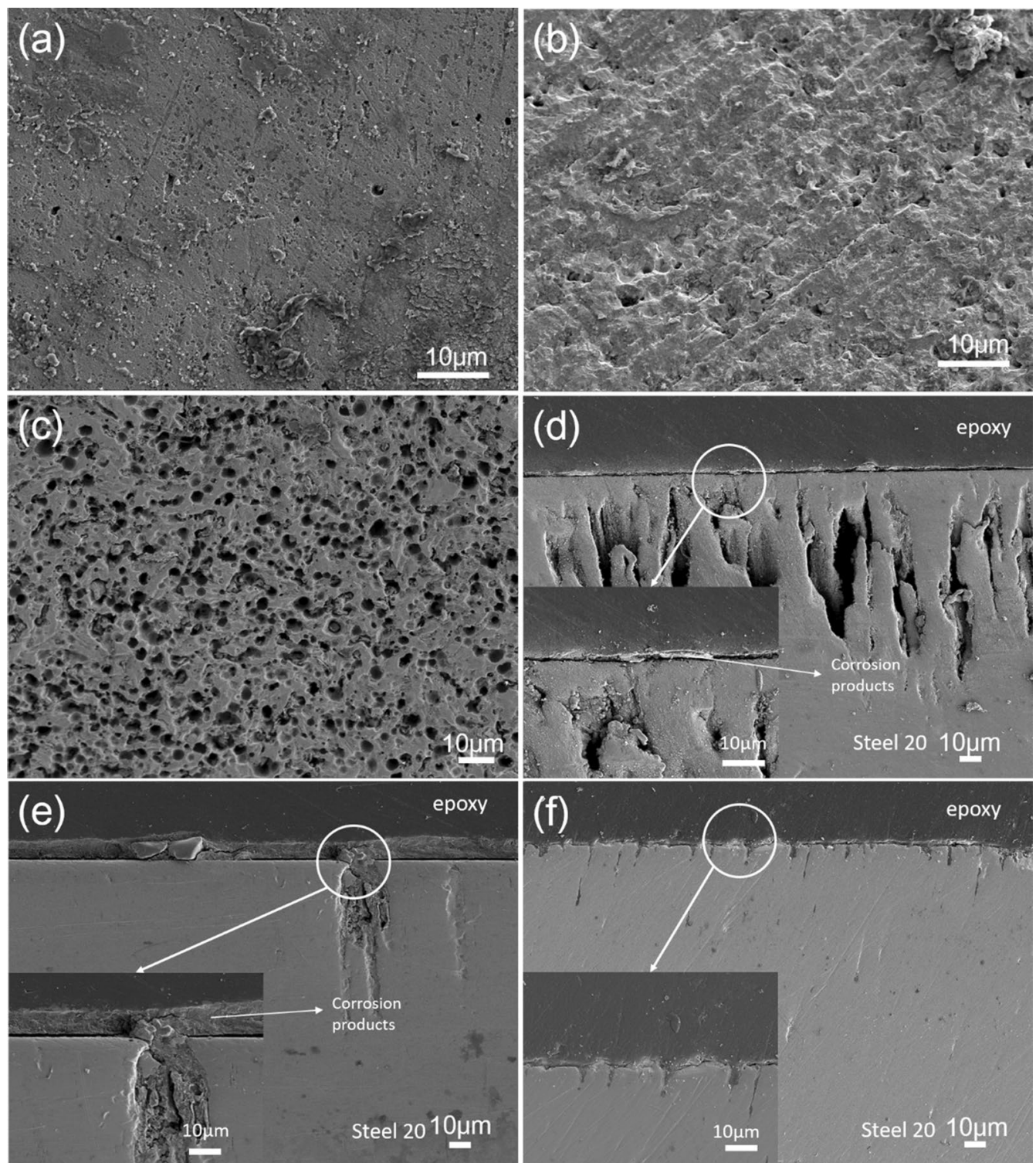

Fig. 10 SEM images of the drawn steel 20 in the $\mathrm{Cu}-\mathrm{Fe} \mathrm{GC}$ after immersing in the simulated solution for $48 \mathrm{~h}$ : the surface without removing corrosion products of drawn steel 20 immersing in the simulated solution with $\mathbf{a} \mathrm{pH}=2.4, \mathbf{b} \mathrm{pH}=4.4, \mathbf{c} \mathrm{pH}=6$ and the cross section of drawn steel 20 immersing in the simulated solution with $\mathbf{d ~ p H}=2.4, \mathbf{e ~ p H}=4.4, \mathbf{f} \mathrm{pH}=6$ (the insets in $\mathbf{d}, \mathbf{e}, \mathbf{f}$ are partial enlargement)

inferred. In the absence of coupling with copper, although the pearlite begins to dissolve, the iron ions will hydrolyze near the corrosion location to form corrosion production. This inhibits the further corrosion of the active point and eliminates the difference in activity between ferrite and pearlite. Therefore, the surface of electrode is uniformly corroded.

\section{Conclusions}

The corrosion behavior of the $\mathrm{Cu}-\mathrm{Fe}$ GC in the acidic red soil simulated solution with different $\mathrm{pH}$ values is studied. The following conclusions may be drawn:
1. The corrosion rate of drawn steel 20 coupled with copper in the simulated solution increases with decreasing $\mathrm{pH}$. The galvanic current of $\mathrm{Cu}-\mathrm{Fe} \mathrm{GC}$ increases with decreasing $\mathrm{pH}$, while the galvanic effect in the acid solution is weaker than that in neutral solution.

2. The corrosion form of $\mathrm{Cu}-\mathrm{Fe} \mathrm{GC}$ is transformed from uniform corrosion to pitting corrosion with increasing $\mathrm{pH}$, which could be attributed to the metallographic structure of drawn steel 20 and the fast migration of the ions under the action of electric field formed by copper and drawn steel 20.

3. The compositions of the rust formed on the surface of drawn steel 20 coupled with the copper are mainly 

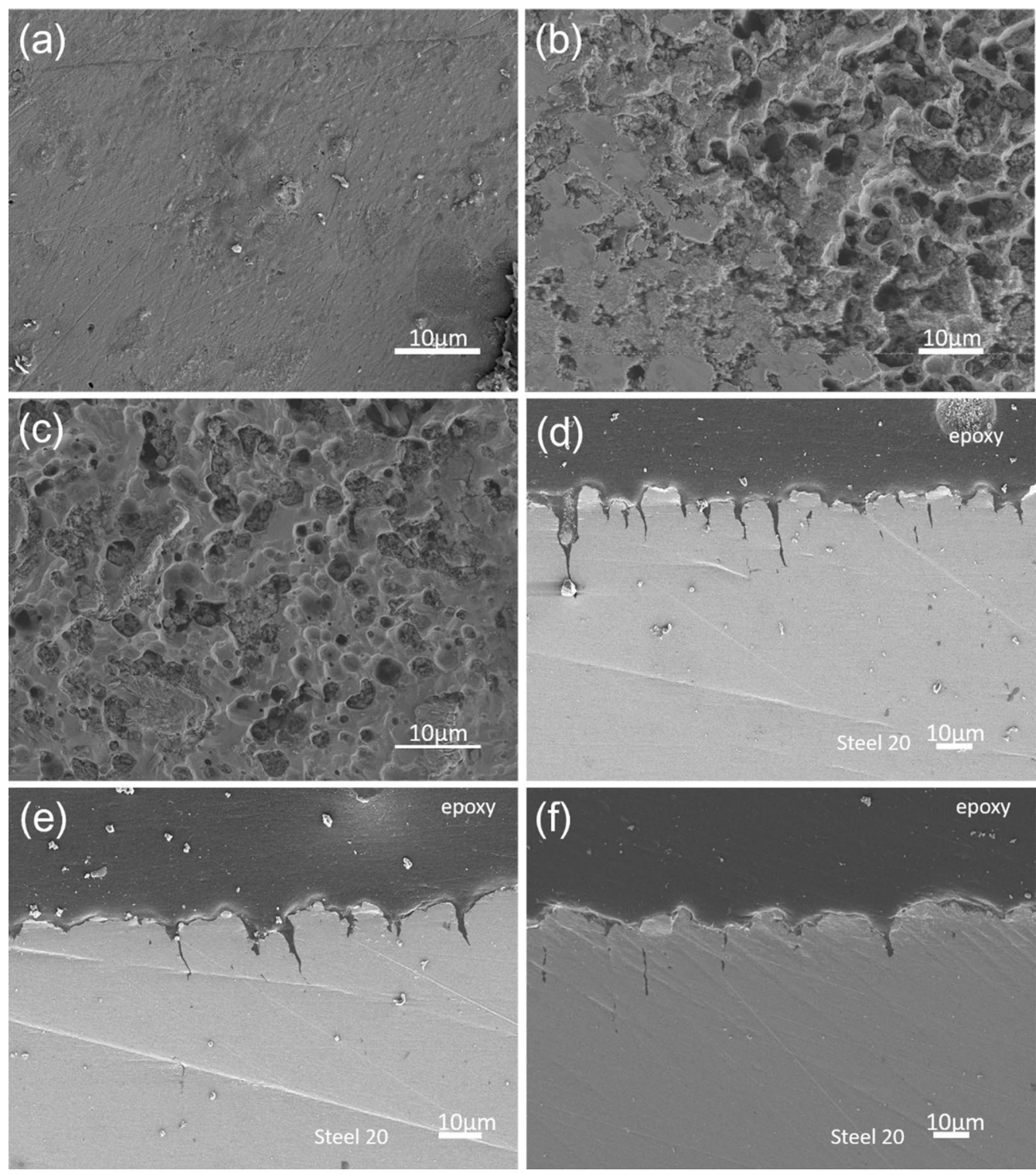

Fig. 11 SEM images of the drawn steel 20 not coupled with copper after immersing in the simulated solution for $48 \mathrm{~h}$ : the surface without removing corrosion products of drawn steel 20 immersing in the simulated solution with $\mathbf{a} \mathrm{pH}=2.4, \mathbf{b} \mathrm{pH}=4.4, \mathbf{c} \mathrm{pH}=6$ and the cross section of drawn steel 20 immersing in the simulated solution with $\mathbf{d ~ p H}=2.4, \mathbf{e} \mathrm{pH}=4.4, \mathbf{f} \mathrm{pH}=6$

unstable $\gamma$ - $\mathrm{FeOOH}$ with porous structure in neutral solution. When $\mathrm{pH}$ in the solution decreases, $\gamma-\mathrm{FeOOH}$ is transformed into $\alpha-\mathrm{FeOOH}$ and $\gamma-\mathrm{Fe}_{2} \mathrm{O}_{3}$ continuously.

Acknowledgements This work was financially supported by the Science and Technology Commission of Shanghai Municipality (No. 19DZ2271100). The authors thank Dr. Xue-Yuan Zhang for his proofreading.

\section{References}

[1] Y.P. Shao, M.M. Mu, B. Zhang, K.B. Nie, Q.Q. Liao, J. Mater. Eng. Perfom. 26, 1751 (2017)

[2] F. Pei, X. Liu, L.L. Jia, C.F. Li, X. Tian, Effects of $\mathrm{pH}$ and chloride ions on the corrosion behavior of zinc-clad steel in the simulated soil solution. Paper presented at the 2016 International Conference on Applied Mechanics, Mechanical and Materials Engineering, Jiangxi Electric Power Research Institute, Feng Pei (2016) 
[3] W. Wei, X.Q. Wu, W. Ke, S. Xu, B. Feng, B.T. Hu, J. Mater. Eng. Perfom. 25, 518 (2016)

[4] I.S. Cole, D. Marney, Corros. Sci. 56, 5 (2012)

[5] S. Srikanth, T.S.N. Sankaranarayanan, K. Gopalakrishna, B.R.V. Narasimhan, T.V.K. Das, S.K. Das, Eng. Fail. Anal. 12, 634 (2005)

[6] A.I.M. Ismail, A.M. El-shamy, Appl. Clay Sci. 42, 356 (2009)

[7] W. Wei, X.Q. Wu, W. Ke, S. Xu, B. Feng, B.T. Hu, J. Mater. Eng. Perform. 26, 4340 (2017)

[8] T.Q. Wu, M.C. Yan, D.C. Zeng, J. Xu, C.K. Yu, C. Sun, W. Ke, Acta Metall. Sin. Engl. Lett. 28, 93 (2014)

[9] Z. Li, H. Wan, D. Song, X. Liu, Z. Li, C. Du, Bioelectrochemistry 126, 121 (2019)

[10] L.S. Qi, C.W. Du, X.G. Li, J.L. Zhou, Acta Metall. Sin. Engl. Lett. 23, 396 (2010)

[11] A.M. El-Shamy, M.F. Shehata, A.I.M. Ismail, Appl. Clay Sci. 114, 461 (2015)

[12] J. Fu, F. Pei, Z.P. Zhu, Z.H. Tan, T. Xu, R.J. Mao, L.J. Wang, Anti-Corros. Methods Mater. 60, 148 (2013)

[13] E.A. Noor, A.H. Al-Moubaraki, Arab. J. Sci. Eng. 39, 5421 (2014)

[14] B. He, P.J. Han, L.F. Hou, D.C. Zhang, X.H. Bai, Eng. Fail. Anal. 80, 325 (2017)

[15] J. Li, H. Su, F. Chai, X.P. Chen, X.Y. Li, H.M. Meng, J. Iron. Steel Res. Int. 22, 352 (2015)

[16] M.C. Yan, S. Yang, C. Sun, J. Xu, T.Q. Wu, W. Ke, Corros. Sci. 93, 27 (2015)

[17] F.L. Ma, R.Z. Xie, P.J. Han, X.H. Bai, Int. J. Electrochem. Sci. 13, $5396(2018)$

[18] Z.Y. Liu, C.W. Du, X. Zhang, F.M. Wang, X.G. Li, Acta Metall. Sin. Engl. Lett. 26, 489 (2013)

[19] B.X. Wei, Q.Y. Qin, Y.L. Bai, C.K. Yu, J. Xu, C. Sun, W. Ke, Eng. Fail. Anal. 105, 156 (2019)

[20] J. Toribio, E. Ovejero, Corros. Sci. 49, 3539 (2007)

[21] J. Toribio, E. Ovejero, Eng. Fail. Anal. 12, 654 (2005)

[22] M. Topic, C. Allen, R. Tait, Int. J. Fatigue 29, 49 (2007)

[23] T.J. Chen, B.Q. Yang, B. Li, J.L. Guo, P. Zhang, X.Z. Cao, J. Mater. Process. Technol. 275, 116375 (2020)

[24] F. Mansfeld, D.H. Hengstenberg, J.V. Kenkel, Corrosion 30, 343 (1974)

[25] H.I.A. Hossani, T.M.H. Saber, R.A. Mohammed, A.M.S.E. Din, Desalination 109, 25 (1997)

[26] Z.F. Yin, M.L. Yan, Z.Q. Bai, W.Z. Zhao, W.J. Zhou, Electrochim. Acta 53, 6285 (2008)

[27] C. Arya, P.R.W. Vassie, Cem. Conc. Res. 25, 989 (1995)

[28] G.L. Song, B. Johannesson, S. Hapugoda, D. StJohn, Corros. Sci. 46, 955 (2004)
[29] C.F. Dong, K. Xiao, X.G. Li, Y.F. Cheng, Wear 270, 39 (2010)

[30] R. Sánchez-Tovar, M.T. Montañés, J. García-Antón, Corros. Sci. 52, $722(2010)$

[31] L.A. Shalaby, Corros. Sci. 11, 767 (1971)

[32] R.M. Souto, Y. González-García, A.C. Bastos, A.M. Simões, Corros. Sci. 49, 4568 (2007)

[33] M.E. El-Dahshan, A.M.S.E. Din, H.H. Haggag, Desalination 142, $161(2002)$

[34] E. Blasco-Tamarit, A. Igual-Muñoz, J.G. Antón, Corros. Sci. 49, $4472(2007)$

[35] E. Blasco-Tamarit, A. Igual-Muñoz, J.G. Antón, D. García-García, Corros. Sci. 50, 3590 (2008)

[36] F.E. Varela, Y. Kurata, N. Sanada, Corros. Sci. 39, 775 (1997)

[37] M. Sancy, Y. Gourbeyre, E.M.M. Sutter, B. Tribollet, Corros. Sci. 52, $1222(2010)$

[38] K.B. Deshpande, Corros. Sci. 52, 2819 (2010)

[39] A.C. Bastos, M.G.S. Ferreira, A.M. Simões, Prog. Org. Coat. 52, 339 (2005)

[40] H.S. Isaacs, Corros. Sci. 28, 547 (1988)

[41] H.S. Isaacs, J. Electrochem. Soc. 138, 722 (1991)

[42] C. Scheffey, Rev. Sci. Instrum. 59, 787 (1988)

[43] A.M. Simões, A.C. Bastos, M.G. Ferreira, Y. González-García, S. González, R.M. Souto, Corros. Sci. 49, 736 (2007)

[44] Q.Z. Ni, X.J. Xia, J.X. Zhang, N.W. Dai, Y.D. Fan, Electrochim. Acta 247, 207 (2017)

[45] S.M. Manhabosco, T.M. Manhabosco, N. Geoffroy, V. Vignal, L.F.P. Dick, Corros. Sci. 140, 379 (2018)

[46] S.K. Oh, Y.J. Kim, K.M. Jung, J.S. Kim, M.Y. Shon, H.S. Kwon, Met. Mater. Int. 23, 290 (2017)

[47] M. Metikoš-Huković, R. Babić, I. Paić, J. Appl. Electrochem. 30, 617 (2000)

[48] F. Mansfeld, Corrosion 27, 436 (1971)

[49] F. Mansfeld, Corrosion 29, 56 (1973)

[50] F. Bellucci, Corrosion 47, 808 (1991)

[51] S.J. Oh, D.C. Cook, H.E. Towndend, Hyperfine Interact. 112, 59 (1998)

[52] G. Nauer, P. Strecha, N. Brinda-Konopik, G. Liptay, J. Therm. Anal. 30, 813 (1985)

[53] D.L.A. De Faria, S. Venâncio Silva, M.T. De Oliveira, J. Raman Spectrosc. 28, 873 (1997)

[54] J. Dunnwald, A. Otto, Corros. Sci. 29, 1167 (1989)

[55] M. Yamashita, H. Miyuki, Y. Masuda, H. Nagano, T. Misawa, Corros. Sci. 36, 283 (1994) 